\title{
Determinants of Malnutrition Under 5 Years Children - A Cross Sectional Study in the Palpa District of Nepal
}

\author{
Deelip Kumar Karki ${ }_{M P H}$, Dr. Dipak K. Bose ${ }_{P h . D .}^{* *}$, Birendra K. Singh ${ }_{M P H}^{* * *}$, \\ Dr. Neena Gupta ${ }^{* * * *}$ Ph.D. Pravin K Khanal ${ }^{* * * * *}{ }_{B P H}$ \\ * Lecturer, Department of Community Medicine, Lumbini Medical College, Palpa \\ **Associate Professor, Department of Extension and Communication, SHUATS, Allahabad \\ ***Assistant Professor, Nobel College of Health Sciences, Kathmandu \\ ****Assistant Professor (Sr.), Department of Public Health, SHUATS, Allahabad \\ ***** Health Assistant, District Public Health Office, Palpa
}

\begin{abstract}
Malnutrition is a pathological state resulting from a relative or absolute deficiency or excess of one or more essential nutrients. Malnutrition continues to be a primary cause of ill health and mortality among children in developing countries. It is a major public health problem and accounts for abouthalf of all child deaths worldwide. Since deficient physical growth is naturally reflected in their suboptimal mental achievement. As per the findings of Nepal Demographic and Health Survey (NDHS, 2011) stunting is 41 per cent, while underweight and wasting, 29 per cent and 11 per cent respectively. The main objective of study is to assess the factors responsible for malnutrition of children under 5 years in Palpa district, Nepal.A cross sectional community based study was conducted whereas multistage sampling was adopted. A total of 390 respondents age between 6-59 months were selected for present study. It was observed that one fifth (20.51\%) of children were mild malnourished followed by 5.13 per cent were moderate malnourished on the basis of weight for age. On the basis of height for age, around one quarter (22.31\%) were mildly impaired, followed by 3.84 per cent were moderately and 1.03 per cent severely impaired. On the basis of weight for height, mild impaired children were 4.62 per cent, moderate impaired 1.79 per cent and severe impaired were 0.51 per cent. Huge numbers of children (60.60\%) were malnourished whose mothers were illiterate. More than three quarter of respondents (78.71\%) had received four ANC visit according to schedule. Majority of respondents (80.76\%) had taken full course of iron tablet during pregnancy and after delivery of the 42 days, who had not taken full course of iron tablet their children were more likely to be malnourished (OR=5.40, $p<0.005)$. Similarly, 76.15 per cent respondents had introduced breastfeeding within 1 hour and large number of respondents (91.79\%) had introduced exclusive breastfeeding up to 6 months. The respondents who were not fed colostrum to their children were more likely to be malnourished (OR=9.06, $p<0.005)$. Almost half $(47.83 \%)$ children were malnourished who had not completed full immunizationwhereas only 23.26 per cent were malnourished among completion of immunization. Likewise, 63.64 per cent children were sick whose mothers were illiterate, 67.45 per cent children had taken normal amount of calorie as recommended level. More than half (59.43\%) of the children were stunted and almost similar number (56.53\%) of children were underweight among those who consumed low calories. Maternal education, immunization status, history of disease, colostrum feeding, exclusive breastfeeding, receiving of iron tablet, consumption of calorie all are important determinants for malnutrition.
\end{abstract}

Keywords: underweight, stunted, wasted, anthropometry and malnutrition

\section{Introduction}

Adequate nutrition is a fundamental right for every human being but around 10.8 million children under five years death is attributed to malnutrition worldwide each year. Malnutrition is one of the major public health problem in developing countries, remains a serious obstacle to child survival, growth and development.It is a man-made disease and begins quite commonly in the womb and ends in the grave. Malnutrition has been defined as "a pathological state resulting from a relative or absolute deficiency or excess of one or more essential nutrients". Malnourished children do not grow to their full potential of physical and mental abilities. It does not only directly affect the children by reducing their physical and mental performance but also makes the situation worse by making the children susceptible to infection, recovery is slower and mortality is higher. It is one of the foremost underlying causes of the child morbidity and mortality. Primary causes of child mortality are: pneumonia, diarrhoea, measles, low birth weight and malaria. Malnutrition is the underlying cause of one out of every two such deaths. Nearly 40 per cent of the under five mortality results from the episodes of diarrhoea or Acute Respiratory Infections; which are curable in first stage with simple home remedies when nutritional status is good. Children who suffer from repeated episodes of diarrhoea or ARI are more likely to 
suffer from malnutrition. Moreover, it passes from one generationto the next as maternal undernutrition increases the risk of intrauterine growth retardation,low birth weight leading to the perpetuationof the malnutrition inter-generationalcycle.

The common types of malnutrition in Nepal are: protein energy malnutrition, iodine deficiency disorders, iron deficiency anemia and vitamin A deficiency. Protein Energy Malnutrition constitutes a serious threat to the survival of young children in Nepal. PEM covers a wide spectrum of clinical stage ranging from the severe form like kwashiorkor and marasmus to the milder form in which the main detectable manifestation is growth retardation. Main causes of PEM are food gap and infections notably diarrhoea, respiratory infection, measles and intestinal worms which increase requirements of calories, protein and other nutrients while the decrease their absorption and utilization. It plays a vicious cycle, infection contributing to malnutrition and malnutrition contributing to infection, both acting synergistically. There are other contributory factors such as poverty, poor environmental condition, large family size, poor maternal health, failure of lactation, adverse cultural practices, illiteracy and lack of accessibility of health services. Maternal education is also an importantfactors because if she, is well educated, has enough knowledge about nutrition then she is able to prepare balance diet for children, as well as knowledge about health then able to use of maternal and child health services, maintainpersonal hygiene, importance of ANC checkup, importance of iron tablet, neonatal checkup, vaccination, exclusive breast feeding, health-seeking behaviour, use of preventive health-care service, thereby reducing the risk of infectious disease, aware of nutritional requirements and improve nutritional status of children. Another important factor is early initiation of breastfeeding and exclusive breastfeeding which cut down the prevalence of malnutrition. Early initiation of breastfeeding is important for both the mother and the child. Colostrum is highly nutritious and contains antibodies that provide natural immunity to the infant. It is recommended that children be fed colostrum immediately after birth preferably within a hour. UNICEF and WHO recommend that children be exclusively breastfed (no other liquid, solid food, or plain water) during the first six months of life.

As per finding of NDHS 2011, 41 per cent stunting, 29 per cent underweight and 11 per cent wasting under 5 year children in Nepal which is public health problem. Nutritional assessment has been the single most important measurement that best defines their health and nutritional status.

\section{Objectives of the study:}

1. To assess the nutritional status of children under 5 years

2. To identify the factors responsible for malnutrition

\section{Study design}

\section{Material And Methods}

It was a community based cross sectional descriptive study.

Study area

There are 5 Developmental regions, 14 Zones and 75 districts in Nepal. Palpa district of Nepal was selected for the present study. It lies in the middle hills of Nepal and at an altitude of 1400 meters from sea level. There are 65 VDCs in Palpa district and 13 VDCs were selected.

\section{Study Population:}

The children aged 6 months to 5 years were selected for present study whereas mothers or care givers of children were the respondents.

\section{Determination of Sample size}

The following formula was used to calculate the sample size

$\mathrm{n}=\mathrm{z}^{2} \mathrm{pq} / \mathrm{e}^{2}$

$$
\begin{aligned}
& =(1.96)^{2} * 0.49 * 0.51 /(0.05)^{2} \\
& =384 \\
& \text { So, respondents were taken } 390 \\
& \mathrm{n}=\text { sample size } \\
& \mathrm{z}=1.96 \text { for } 95 \% \text { confidence interval }(\mathrm{CI}) \\
& \mathrm{p}=\text { Prevalence }=49 \%(0.49) \\
& \mathrm{q}=1-\mathrm{p}=(0.51) \\
& \mathrm{e}^{2}=\text { permissible error }=5 \%(0.05)
\end{aligned}
$$

Note: $49 \%$ of the children below 5 years are affected by stunting (NDHS, 2006)

\section{Sampling technique:}

Multi stage sampling was adopted for present study. Palpa district was selected purposively. There are 65 VDCs in Palpa district, Names of 65 VDCs were recorded alphabeticallyand then 13 VDCs were selected by random sampling. There are 9 wards in each VDC. Numbers of wards were written orderly like 1, 2, 3, 4, 5, 6, 
Determinants of Malnutrition Under 5 Years Children - A Cross Sectional Study in the Palpa ..

7, 8, 9 and out of 9 wards, 3 wards were selected by random sampling.Total population of district 6 months to 5 years children are 38668. Total numbers of 6 months to 5 years children were listed ward-wise by using Vitamin A register of Female Community Health Volunteer (FCHV). 10 respondents were selected from each ward by systematic random sampling. Thus a total of 390 children were selected for the study.

\section{Data collection toolsand techniques}

A structured interview schedule was developed. Pre-testing was done and final tool was developed after the feedback from pre-testing. Data was collected by face to face interview by researcher himself. Informed verbal consent from the respondents was taken.Nutritional status was measured by anthropometric measurement whereas weight is taken in kilogram, with the help of weighing machine, height of the child was measured with the help of measuring tape in Cm and Mid Upper Arm Circumference (MUAC) of left hand was measured by usingshakir tape. Weight for age (underweight) and height for age (stunting) and weight for height (wasting) was measured according to Gomez and Waterlow's classification.

Gomez Classification:

Uses weight-for-age measurements

$$
\text { Weight of the child }=\text { Weight forage } \quad \times 100
$$

Weight for normal child of same age

Weight-for-Age\%

$90-110$

$75-89$

$60-74$

$<60$
Status

Normal nutritional status

$1^{\text {st }}$ degree, mild malnutrition

$2^{\text {nd }}$ degree, moderate malnutrition

$3^{\text {rd }}$ degree, severe malnutrition

\section{Waterlow's Classification:}

This is used mainly for distinguishes between deficits of weight-for-height (wasting) and height-for-age (stunting) which is adopted by WHO.

\begin{tabular}{|l|c|c|}
\hline Height/Age $\backslash$ Weight/Height & >m -2 SD & <m -2SD \\
\hline$>\mathrm{m}-2 \mathrm{SD}$ & Normal & Wasted \\
\hline$<\mathrm{m}-2 \mathrm{SD}$ & Stunted & Wasted and Stunted \\
\hline
\end{tabular}

Weight of the child $=$ Weight for Height $(\%)$

Weight of a normal child at same height

\section{Height of the child $=\quad$ Height forAge $(\%)$}

Height for normal child at same age

Interpretation of indicators:

\begin{tabular}{|l|c|c|}
\hline Nutritional status & $\begin{array}{c}\text { Stunting } \\
\text { (Height-for-Age \%) }\end{array}$ & $\begin{array}{c}\text { Wasting } \\
\text { (Weight-for-Height\% })\end{array}$ \\
\hline Normal & $>95$ & $>90$ \\
\hline Mildly impaired & $87.5-95$ & $80-90$ \\
\hline Moderately impaired & $80-87.5$ & $70-80$ \\
\hline Severely impaired & $<80$ & $<70$ \\
\hline
\end{tabular}

Mid Upper Arm circumference:

\begin{tabular}{|l|c|c|}
\hline MUAC & Colour & Nutritional status \\
\hline$>13.5$ & Green & Well \\
\hline $12.5-13.5$ & Yellow & Mild \\
\hline$<12.5$ & Red & Severe \\
\hline
\end{tabular}


Determinants of Malnutrition Under 5 Years Children - A Cross Sectional Study in the Palpa ..

\section{Assessment of dietary intake:}

Another measure to identify nutritional status, which is the most common and practical method, that is assessment of dietary intake. The food intake was measured using 24 hours dietary recall method. Mother/care giver, the primary source of recall, were asked to recall all foods consumed by the child during the last 24 hours. For assessment of dietary intake, under 2 years children were excluded because of breastfeeding.

\section{The use of statistical test in research}

Data coding and editing was done manually. Entry and analysis was done by using SPSS version 16.0. The use of statistical tests like Mean, Median, Chi-square test Odds ratio and multivariate analysis was used to analyze the data.

Period of study: Data was collected from November, 2012 to October 2013 by using structured interview schedule.

\subsection{Socio demographic characteristics:}

\section{Results And Discussion}

The study shows that majority of respondents were 20-30 years of age group, 92.05 per cent respondents were Hindu followed by 5.12 per cent were Christian. Around half respondents had passed the primary level of education, 32.82 per cent had passed secondary level and 8.46 per cent were illiterate. majority of the respondents (84.62\%) were housewife, 9.74 per cent were involved in agriculture and only1.28 per cent were involved in business. Around half (47.18\%) family had more than 90,000 annual income, followed by 23.08 per cent had 50,001 to 70, 0000. Majority of respondents (59.49\%) got married at the age of 18 to 20 years, 14.62 per cent in 21-23 years and 5.64 per centin less than 15 years (Mean - 18.65, SD \pm 2.30 ). Similarly, 46.92 per cent respondents were from 18 to 20 years of age group when they were pregnant at first time, 17.18 per cent were in between 15 to 17 years and very few (2.82\%) between 24 to 26 years of age group (Mean 20.25 , SD \pm 2.89 ). Study also depicts that one fourth $(25.90 \%)$ children were from 6-11 months of age group followed by 16.67 per cent were from 54-59 months, very few (2.05\%) were from $42-47$ months of age group.

\subsection{Information regarding $\mathrm{MCH}$}

\begin{tabular}{|c|c|c|}
\hline \multicolumn{3}{|c|}{ Frequency of ANC visit during pregnancy } \\
\hline Frequency of visit & Frequency & Percentage \\
\hline Four times & 307 & 78.71 \\
\hline Partial & 83 & 21.29 \\
\hline \multicolumn{3}{|c|}{ Iron tablet received during pregnancy and post-partum } \\
\hline Full course & 315 & 80.76 \\
\hline Partial & 75 & 19.24 \\
\hline \multicolumn{3}{|c|}{ Albendazole tablet received after first trimester of pregnancy } \\
\hline Yes & 376 & 96.41 \\
\hline No & 14 & 3.59 \\
\hline \multicolumn{3}{|l|}{ Administration of Colostrum } \\
\hline Colostrum administration & Frequency & Percentage \\
\hline Yes & 382 & 97.94 \\
\hline No & 8 & 2.06 \\
\hline \multicolumn{3}{|c|}{ First breastfeeding after delivery (Time) } \\
\hline Within 1 hour & 297 & 76.15 \\
\hline $1-12$ hours & 93 & 23.85 \\
\hline \multicolumn{3}{|c|}{ Duration of exclusive breastfeeding } \\
\hline 4 months & 6 & 1.54 \\
\hline 5 months & 14 & 3.59 \\
\hline 6 months & 358 & 91.79 \\
\hline Do not know & 12 & 3.08 \\
\hline \multicolumn{3}{|c|}{ Immunization status of children } \\
\hline Complete & 344 & 88.20 \\
\hline Incomplete & 46 & 11.80 \\
\hline
\end{tabular}

Above table illustrates that majority of respondents (78.71\%) had received four ANC visit according to schedule and 21.29 per cent had taken less than four ANC services. As well as,80.76 per cent had taken full course of iron tablet during pregnancy and after delivery of the 42 days but 19.24 per cent mothers had taken partially. Similarly, 96.41 per cent respondent had taken albendazole after first trimester of pregnancy but 3.59 per cent had not taken. Most of the respondents (97.94\%) had administered colostrum (first milk) to new borne baby but 2.06 per cent did not.Above table also reveals that around three quarter $(76.15 \%)$ of the respondents had introduced breastfeeding within 1 hour and rest of the mothers $(23.85 \%)$ had introduced 1 to 12 hours after delivery. As well as,majority of the respondents (91.79\%) had introduced exclusive breastfeeding up to 6 months and very few $(1.54 \%)$ reported until 4 months. Likewise, most of the children $(88.20 \%)$ had completed their vaccination but 11.80 per cent had not completed. 
Determinants of Malnutrition Under 5 Years Children - A Cross Sectional Study in the Palpa ..

\subsection{Nutritional status of the children}

\begin{tabular}{|c|c|c|}
\hline Nutritional status & Frequency & Percentage \\
\hline \multicolumn{3}{|c|}{ Nutritional status of the children (Underweight): Weight-for-age* } \\
\hline Normal $(90-110 \%)$ & 288 & 73.85 \\
\hline Mild malnutrition (Gr. I) (75-89\%) & 80 & 20.51 \\
\hline Moderate malnutrition (Gr. II) (60-74\%) & 20 & 5.13 \\
\hline Severe malnutrition (Gr. III) $(\leq 60 \%)$ & 2 & 0.51 \\
\hline \multicolumn{3}{|c|}{ *Weight for age calculated according to Gomez Classification (WHO standard) } \\
\hline \multicolumn{3}{|c|}{ Nutritional status of the children (Stunted): Height-for-age* } \\
\hline Normal (>95\%) & 284 & 72.82 \\
\hline Mild Impaired (87.5\%-95\%) & 87 & 22.31 \\
\hline Moderate Impaired $(80 \%-87.5 \%)$ & 15 & 3.84 \\
\hline Severely Impaired $(<80 \%)$ & 4 & 1.03 \\
\hline \multicolumn{3}{|c|}{ Nutritional status of the children (Wasted): Weight-for-height* } \\
\hline Normal $(>90 \%)$ & 363 & 93.08 \\
\hline Mild Impaired (80\%-90\%) & 18 & 4.62 \\
\hline Moderate Impaired (70\%-80\%) & 7 & 1.79 \\
\hline Severely Impaired $(<70 \%)$ & 2 & 0.51 \\
\hline \multicolumn{3}{|c|}{ *Height for age and weight for height according to Waterlow's classification } \\
\hline \multicolumn{3}{|c|}{ Nutritional status of the children: MUAC measurement } \\
\hline Well Nutritional Status & 288 & 73.84 \\
\hline Mild Malnutrition & 102 & 26.16 \\
\hline
\end{tabular}

Above table illustrates that majority of children $(73.85 \%)$ were normal in weight but around one fifth (20.51\%) were mild malnourished followed by 5.13 per cent were moderate malnourished and very few $(0.51 \%)$ were severe malnourished.Similarly, 72.82 per cent children were normal in height but 22.31 per cent were mildly impaired, followed by 3.84 per cent were moderately impaired and 1.03 per cent were severely impaired. In respect to weight for height, most of the children (93.08\%) were normal, 4.62 per cent were mildly impaired and 0.51 per cent were severely impaired. On the basis of measurement of MUAC, 73.84 per cent children were well nourished and around one quarter $(26.16 \%)$ children were mild malnourished.

Table 3.4 Relation between nutritional status of the children (weight for age) and other variables

\begin{tabular}{|c|c|c|c|}
\hline Sex & Normal & Malnutrition & Total \\
\hline Male & $182(78.11)$ & $51(21.89)$ & $233(100.00)$ \\
\hline Female & $106(67.51)$ & $51(32.49)$ & $157(100.00)$ \\
\hline \multicolumn{4}{|c|}{$\chi^{2} \mathrm{cal}=5.452, \mathrm{df}=1, \chi^{2}$ tab $=3.99, \mathrm{P}$ value $=.020$ (Significant) } \\
\hline \multicolumn{4}{|c|}{ Education of the respondents } \\
\hline Illiterate & $13(39.40)$ & $20(60.60)$ & $33(100.00)$ \\
\hline Primary & $148(76.29)$ & $46(23.71)$ & $194(100.00)$ \\
\hline Secondary & $105(82.03)$ & $23(17.97)$ & $128(100.00)$ \\
\hline Intermediate & $22(62.85)$ & $13(37.15)$ & $35(100.00)$ \\
\hline \multicolumn{4}{|c|}{$\chi^{2} \mathrm{cal}=27.50, \mathrm{df}=3, \chi^{2} \mathrm{tab}=7.81, \quad \mathrm{P}$ value $=.000$ (Significant) } \\
\hline \multicolumn{4}{|c|}{ Immunization status of children } \\
\hline Complete & $264(76.74)$ & $80(23.26)$ & $344(100.00)$ \\
\hline Incomplete & $24(52.17)$ & $22(47.83)$ & $46(100.00)$ \\
\hline & $\mathrm{al}=12.683$, & $P$ value $=0.00$ & $=3.025$ \\
\hline
\end{tabular}

*Figures in the parenthesis denote percentage

Above table shows that 32.49 per cent female children and only 21.89 per cent male children were malnourished. Majority of children $(60.60 \%)$ were malnourished whose mothers were illiterate and only 37.15 per cent were malnourished whose mothers had completed intermediate level.Similarly, 47.83 per cent children were malnourished who had not completed immunization whereas only one fourth of the children $(23.26 \%)$ were malnourished among completion of immunization schedule. There is significant association between nutritional status and immunization of children.

Table 3.5 Relation between nutritional status (Height for age) and maternal education

\begin{tabular}{|l|c|c|c|}
\hline \multicolumn{1}{|c|}{ Characteristics } & Normal & Malnutrition & \multirow{2}{*}{ Total } \\
\hline Education of mother & $14(42.42)$ & $19(57.58)$ & $33(100.00)$ \\
\hline Illiterate & $146(75.25)$ & $48(24.75)$ & $194(100.00)$ \\
\hline Primary & $96(75.00)$ & $32(25.00)$ & $128(100.00)$ \\
\hline Secondary & $28(80.00)$ & $7(20.00)$ & $35(100.00)$ \\
\hline Intermediate $\chi^{2} \mathrm{cal}=17.206$, & $\mathrm{df}=3, \chi^{2} \mathrm{tab}=7.81, \quad$ P value $=0.001$ (Significant) \\
\hline \multicolumn{2}{|c|}{}
\end{tabular}

*Figures in the parenthesis denote percentage

Above table reveals that 57.58 per cent children were stunted whose mothers were illiterate and 80.00 per cent children were normal in height whose mother completed intermediate level of education. 
Determinants of Malnutrition Under 5 Years Children - A Cross Sectional Study in the Palpa ..

Table 3.6 Relation between Nutritional status (weight for age) and MCH characteristics

\begin{tabular}{|c|c|c|c|}
\hline \multirow[t]{2}{*}{ Characteristics } & \multicolumn{2}{|c|}{ Nutritional status } & \multirow[t]{2}{*}{ Total } \\
\hline & Normal & Malnutrition & \\
\hline \multicolumn{4}{|l|}{ Place of delivery } \\
\hline Hospital & $220(79.71)$ & $56(20.29)$ & $276(100.00)$ \\
\hline Home & $68(59.64)$ & $46(40.36)$ & $114(100.00)$ \\
\hline \multicolumn{4}{|c|}{$\chi^{2}$ cal $=16.811, \quad \mathrm{df}=1, \chi^{2}$ tab $=1.34 \quad \mathrm{P}$ value $=.000$ (Significant) $\mathrm{OR}=2.65$} \\
\hline \multicolumn{4}{|c|}{ Administration of Colostrum } \\
\hline Yes & $287(75.13)$ & $95(24.87)$ & $382(100.00)$ \\
\hline No & $2(25.00)$ & $6(75.00)$ & $8(100.00)$ \\
\hline \multicolumn{4}{|c|}{$\chi^{2} \mathrm{cal}=15.915, \quad \mathrm{df}=1, \chi^{2} \mathrm{tab}=1.34 \quad \mathrm{P}$ value $=.000$ (Significant) $\mathrm{OR}=9.06$} \\
\hline \multicolumn{4}{|c|}{ Duration of Breastfeeding } \\
\hline Up to 6 months & $277(77.37)$ & $81(22.62)$ & $358(100.00)$ \\
\hline Less than 6 months & $11(34.37)$ & $21(65.63)$ & $32(100.00)$ \\
\hline \multicolumn{4}{|c|}{$\chi^{2}$ cal $=30.715, \quad \mathrm{df}=2, \chi^{2}$ tab $=5.99 \quad \mathrm{P}$ value $=.000$ (Significant) $\mathrm{OR}=1.93$} \\
\hline \multicolumn{4}{|c|}{ Iron tablet received during pregnancy and post-partum } \\
\hline Full course & $255(81.00)$ & $60(19.00)$ & $315(100.00)$ \\
\hline Partial & $33(44.00)$ & $42(56.00)$ & $75(100.00)$ \\
\hline \multicolumn{4}{|c|}{$\chi^{2} \mathrm{cal}=42.828, \quad \mathrm{df}=1, \chi^{2} \mathrm{tab}=1.34 \quad \mathrm{P}$ value $=.000$ (Significant) $\mathrm{OR}=5.40$} \\
\hline
\end{tabular}

Above table shows that 79.71 per cent children were normal who were born in hospital but 59.64 per cent children were normal and 40.36 per cent children were malnourished who were born in home. Similarly, 25.00 per cent children were normal and 75.00 per cent were malnourishedamong those who were deprived from colostrum. As well as, 65.63 per cent children were malnourished who had got breastfeeding less than 6 months and 22.62 per cent children were malnourished who had got breastfeeding up to 6 months which shows there is relationship between nutritional status of children and duration of breastfeeding. Likewise, only 19.00 per cent children were malnourished whose mother had taken full course of iron but 56.00 per cent children were malnourished who had not taken full course.

Table 3.7 Relation between calorie consumption and age of children in month

\begin{tabular}{|l|c|c|c|c|c|c|}
\hline \multirow{2}{*}{$\begin{array}{l}\text { Calorie } \\
\text { consumption }\end{array}$} & \multicolumn{7}{|c|}{ Age of children in months } \\
\cline { 2 - 7 } & $\mathbf{2 4 - 2 9}$ & $\mathbf{3 0 - 3 5}$ & $\mathbf{3 6 - 4 1}$ & $\mathbf{4 8 - 5 3}$ & $\mathbf{5 4 - 5 9}$ & Total \\
\hline Normal & $7(4.89)$ & $10(6.99)$ & $41(28.67)$ & $36(25.18)$ & $49(34.27)$ & $143(100.0)$ \\
\hline Low & $4(5.79)$ & $2(2.88)$ & $15(21.79)$ & $32(46.37)$ & $16(23.17)$ & $69(100.0)$ \\
\hline Total & $11(5.18)$ & $12(5.66)$ & $56(26.42)$ & $68(32.07)$ & $65(30.67)$ & $212(100.0)$ \\
\hline
\end{tabular}

2-3 years: Mean 1170, SD 274.46

4-5 years: Mean 1645, SD 309.89

*Figures in the parenthesis denote percentage

Above table illustrates that more than one third (34.27\%) children were consumed adequate amount of calorie who were 54 to 59 months of age. Likewise, majority of children (46.37\%) were consumed low amount of calorie who were 48 to 53 months of age group.

Table 3.8 Relation between nutritional status and calorie consumption $\quad(\mathrm{N}=212)$

\begin{tabular}{|l|c|c|c|}
\hline \multirow{2}{*}{$\begin{array}{l}\text { Calorie } \\
\text { consumption }\end{array}$} & Normal Height for age & Total \\
\cline { 2 - 4 } Normal & $132(92.30)$ & Stunted & $143(100.00)$ \\
\hline Low & $28(40.57)$ & $11(7.70)$ & $69(100.00)$ \\
\hline Total & $160(75.47)$ & $41(59.43)$ & $212(100.00)$ \\
\hline \multicolumn{2}{|c|}{} \\
\hline
\end{tabular}

*Figures in the parenthesis denote percentage

Above table shows that majority of children (92.30\%) were normal in height who consumed adequate calorie but 59.43 per cent children were stunted among those who consumed low calories as compared to recommended level.

Table 3.9Relation between history of disease and background characteristics

\begin{tabular}{|c|c|c|c|}
\hline \multirow[t]{2}{*}{ Characteristics } & \multicolumn{2}{|c|}{ History of disease } & \multirow[t]{2}{*}{ Total } \\
\hline & No & Yes & \\
\hline \multicolumn{4}{|l|}{ Immunization status } \\
\hline Complete & 239 (69.47) & $105(30.53)$ & $344(100.0)$ \\
\hline Incomplete & $21(45.65)$ & $25(54.35)$ & $46(100.0)$ \\
\hline \multicolumn{4}{|c|}{$\chi^{2} \mathrm{cal}=10.364, \mathrm{df}=1, \chi^{2}$ tab $=1.34, \mathrm{P}$ value $=.001$ (Significant) $\mathrm{OR}=2.70$} \\
\hline \multicolumn{4}{|c|}{ Nutritional status (Height for age) } \\
\hline Normal & $184(64.78)$ & $100(35.22)$ & $284(100.0)$ \\
\hline Malnutrition & $76(71.69)$ & $30(28.31)$ & $106(100.00)$ \\
\hline
\end{tabular}


Determinants of Malnutrition Under 5 Years Children - A Cross Sectional Study in the Palpa ..

\begin{tabular}{|c|c|c|c|}
\hline \multicolumn{4}{|c|}{ Nutritional status (Weight for age) } \\
\hline Normal & $244(84.72)$ & $44(15.28)$ & $288(100.0)$ \\
\hline Malnutrition & $16(15.68)$ & $86(84.32)$ & $102(100.0)$ \\
\hline
\end{tabular}

*Figures in the parenthesis denote percentage

Above table depicts that 69.47 per cent children had no disease within a month who completed immunization. Majority of the children $(71.69 \%)$ were stunted who were not sick within a month and 28.31 per cent were stunted who were sick. Therefore, there is no association between stunting and morbidity status.Similarly, 15.28 per cent children were normal in weight and 84.32 per cent children were underweight who were sick.

\section{Multivariete analysis}

In multivariate analysis, association between nutritional status (weight for age) and education of mother $(\mathrm{F}=11.120, \mathrm{p}=.026)$, immunization status $(\mathrm{F}=12.643, \mathrm{p}=.000)$, history of disease $(\mathrm{F}=17.548, \mathrm{p}=.000)$, Sex of children $(\mathrm{F}=5.027, \mathrm{p}=.026)$, colostrum feeding $(\mathrm{F}=16.507, \mathrm{p}=.000)$, exclusive breastfeeding $(\mathrm{F}=32.518$, $\mathrm{p}=.000)$, history of illness $(\mathrm{F}=27.36, \mathrm{p}=.000)$, receiving of iron tablet $(\mathrm{F}=6.652, \mathrm{p}=.000)$, and place of delivery $(\mathrm{F}=3.478, \mathrm{p}=.000)$ all are found significant. Similarly, nutritional status (height for age) and education of mother $(\mathrm{F}=5.938, \mathrm{p}=001)$ is also found significant.

\section{Conclusion}

\section{Conclusion And Recommendations}

A cross-sectional study was conducted to identify the factors determinants for malnutrition, a total of 390 respondents were taken. The agebetween 6-59 months children were selected for the present study.

- Majority of the children were from 6-11 months of age group, more than fifty per cent children were boys.

- Around one fifth $(20.51 \%)$ children were mild malnourished followed by 5.13 per cent were moderate malnourished and very few $(0.51 \%)$ were severe malnourished on the basis of weight for age.

- Majority of the children were normal in height but around one quarter $(22.31 \%)$ were mildly impaired and around one per cent were severely impaired.

- In respect to weight for height, most of the children (93.08\%) were normal, 4.62 per cent were mildly impaired and 0.51 per cent were severely impaired.

- On the basis of measurement of MUAC, more than two third (73.84\%) children were well nourished and around one quarter $(26.16 \%)$ children were mild malnourished.

- Maximum children were malnourished whose mothers were illiterate. So, there is association between maternal education and nutritional status.

- Association is also found positive between gender and nutritional status whereas more girls are found malnourished than boys.

- Almost half (47.83\%) children were malnourished who had not completed full immunization whereas only one fourth $(23.26 \%)$ of the children were malnourished who had completed.

- Number of hospital delivery is high which is another important factor for survival of mother and new borne baby.

- Majority of respondents $(80.76 \%)$ had taken full course of iron tablet during pregnancy, who had not taken full course of iron tablet is more likely to be malnourished.

- Almost all mothers had fed colostrum milk to new borne baby. The respondents who had not fed colostrum to their children were more likely to be malnourished.

- Huge numbers of mothers introduced exclusive breastfeeding up to six months. Most of the children, who were not breastfeed exclusively, were malnourished.

- More than half $(59.43 \%)$ of the children were stunted among those who consumed low calories.

- More than half (63.64\%)illiterate mother's children were sick. Similarly, the children whose mothers were literate were comparatively healthy. Chance of malnutrition is higher when the children get sick by communicable disease such as ARI, diarrhoea, worm infestation and measles.

- Maternal education, immunization status, history of disease, colostrum feeding, exclusive breastfeeding, receiving of iron tablet, consumption of calorie all are important determinants for malnutrition.

\section{Recommendations}

- Nutritional awareness program needed to be more focus in order to reduce the malnutrition problem.

- Ensure early initiation of breastfeeding within an hour of birth and promotion of exclusive breastfeeding for the first 6 months 
- Ensure continuation of breast feeding at least for 2 years and introduction of appropriate complementary feeding after 6 months.

- Promotion of balance diet which is helpful for reduction of mortality, morbidity, improved physical, mental and cognitive development of children.

- $\quad$ Promotion of hospital delivery, iron compliance during pregnancy and postpartum.

- Strengthen and promotion of growth monitoring to identify the malnutrition in early stage which is helpful for taking prompt interventionand pay appropriate consideration about full immunization.

- Nutrition surveillance needs to be done continuously and special attention should be given to vulnerable groups such as poorest and the most severely malnourished children.

- Attention should be paid on maternal education and change culturally acceptable nutrition behaviour to improve intake of nutritious foods and diversification of diet.

- Although country already has a nutrition policy, strategies and action plans but important issue is to create an enabling environment for a multi-sectorial approach and bring together to prevent and address malnutrition.

- Appropriate management of common childhood illness such as ARI, diarrhoea, worm infestation, malaria and measles etc. by FCHV, Health Worker in early stage which prevents malnutrition.

- Government should be stable and political commitment for the socioeconomic development.

\section{Acknowledgment}

First of all, I would like to express sincere gratitude to my advisor Dr. Dipak Kumar Bose, Associate Professor, for his suggestion and great positive behaviour during the time of study and research work. It's my great pleasure to extend sincere gratitude to my Co-advisor Dr. Virginia Poul (Associate Professor)as well as Dr. Neena Gupta, Assistant Professor (Sr.) and Dr. A. P. Singh (Professor), for their keen encouragement and suggestion.

No words are enough to express my deep sense of gratitude and love to my parents Mr. Lok Bahadur Karki and Mrs. Bimala Karki, who devoted their entire life for my success, untiring efforts my wife Mrs. Sangita Karki for continuous encouragement and to my lovely son Pawan Karki and daughter Prakriti Karki. At last, but not least, I remain grateful to all known and unknown persons who have contributed for this work knowingly and unknowingly.

\section{References}

[1]. AcharyaDilaram, GautamSalila, KaphleHari Prasad, NirmalaNaupane. (2013) Factors Associated with Nutritional Status of Under Five Children in Rupandehi District of Nepal

[2]. BattalwarRekha. (2014) High prevalence of malnutrition in children under 5 years from rural Thane district, Maharashtra, Voice of Research, Vol. 3 Issue 1, June, ISSN No. 2277-7733

[3]. Bhandari TR and Chhetri M. (2013) Nutritional Status of Under Five Year Children and Factors Associated in KapilvastuDistrict, Nepal. Journal of Nutrition Health Food Science http://dx.doi.org/10.15226/jnhfs.2013.00106

[4]. Chapagain RH, AdhikariAPa, Dahal Ra, SubediJb, BlengeroJc, Williams-BlengeroSc and Towne Bd. (2005)A Study on Nutritional Status of Under Five JirelChildrenof Eastern Nepal. Journal of Nepal Health Research Council Vol.3 No. 2 October 2005

[5]. Dhungana GP. (2014) nutritional status of under 5 children and associated factors of kunchha village development committee, Journal of Chitwan Medical College 2013; 3(6): 38-42, www.jcmc.cmc.edu.np

[6]. Ghimire M. and Ghimire M. (2013) Prevalence of low calorie intake by rural families in Palpa district of Nepal, Journal of Lumbini Medical College, JLMC, Reg. no. 37229/062/063

[7]. Ghosh A, Adhikari P, Chowdhury SD and Ghosh T. (2009) Prevalence of undernutrition in Nepalese children.

[8]. Harshal T. Pandve and Samir A. Singru. (2012) Various Anthropometric Methods of Martorell R, Leslie J and Moock PR. (1984) Characteristics and determinantsof child nutritional status in Nepal.

[9]. Ministry of Health and Population, Population Division. (2011) Department of Health Services, Government of Nepal. Nepal Demographic and Health Survey (NDHS), report. http://www.mohp.gov.np/english/publication

[10]. Park K. (2012) Park's text book of preventive and Social Medicine, 20th.edition

[11]. Pradhan A. (2005) Child nutrition in Nepal.Kathmandu University Medical Journal Vol. 3, No.1, issue 9, pp 2-3

[12]. Sah Nepali. (2004) Determinants of Child Malnutrition in Nepal: A Case Analysis from Dhanusha, Central Terai of Nepal Journal of Nepal Health Research Council Vol. 2 No. 2 October

[13]. Sapkota VP and Gurung CK. (2009) Prevalence and Predictors of Underweight, Stunting and Wasting in Under-Five Children. Journal of Nepal Health Research Council; 7(15):120-26.

[14]. Shakya SR, Bhandary S and Pokharel PK. (2004) Nutritional status and morbidity pattern among governmental primary school children in the Eastern Nepal. Kathmandu Univ Med J (KUMJ). Oct-Dec;2(4):307-14.

[15]. Shankar A. (2000) Nutritional modulation of malaria morbidity and mortality J Infect Dis;182(Suppl 1):S37-53.

[16]. Sharma KR. (2012) Malnutrition in children aged 6-59 months in Mugu district. May;10(21):156-9.

[17]. Yadav DK, Gupta N, Shrestha N. (2014)An assessment of nutritional status of children less than 3 years in rural areas of Mahottari district of Nepal, International Journal of Medical Research\& Health Sciences IJMRHS. 2014; 3(3): 597-603 